\title{
Helping doctoral students crack the publication code: An evaluation and content analysis of the Australasian Journal of Educational Technology
}

\author{
Melissa Bond \\ University of Oldenburg, Germany
}

\begin{abstract}
Getting published in an academic journal is no easy feat, especially for doctoral students and English as a second language speakers, seeking to publish in English. Considering the relatively low acceptance rate for educational technology journals, this article seeks to provide guidance by following the framework of rigour, impact, and prestige (West \& Rich, 2012) to evaluate the Australasian Journal of Educational Technology (AJET), as well as applying computer-assisted content analysis techniques in new and unique ways, in order to understand how AJET is furthering scholarship in the field. Findings reveal a strong focus on Asia-Pacific scholarship, with little representation from other continents. However, the editors are seeking to improve this, by providing regular advice in editorials for conducting rigorous research and hints on how to get published. Future research trends are identified, including teacher development, learning environments and cognition, and the role of feedback in student learning. In addition, recommendations to editors and doctoral students are provided.
\end{abstract}

\section{Introduction}

The world of publishing in academia can be a difficult code to crack, with a great variety in understanding across disciplines as to what defines research excellence (Lamont, 2009). Academics are increasingly being pressured to publish in high quality, leading academic journals (McGrail, Rickard, \& Jones, 2006), considered to be the most highly valued sign of research productivity and quality (Mulligan, Hall, \& Raphael, 2013; Print \& Hattie, 1997). However, with half of all manuscripts rejected, either by editors or as part of the peer review process, and with over half of all citations belonging to a mere $1 \%$ of publications (Fiala, Mares, \& Sestak, 2017), anxiety and concern still abound. For example, in a recent editorial published in the Australasian Journal of Educational Technology (AJET), Redmond, Henderson, and Heinrich (2017) responded to lamentations on social media about desk rejections, calling for cooler heads and a deeper understanding by authors of the peer review process. Whilst this was written for the benefit of all academics, it was explicitly recognised in the article that so-called “minority groups within academia” (Rodriguez, 2015, p. 1061) are struggling the most; that is, academics from non-English speaking countries, and doctoral students/early career researchers.

Doctoral students across all disciplines are being introduced early to the publish or perish mentality (Jackson, 2013; Jones, 2013; Pare, 2010). An increasing number of publication-based dissertations are being completed across Europe, the United Kingdom, and Australia (Lee \& Kamler, 2008), with ongoing disagreement among national institutions about the requirements (Badley, 2009; Jackson, 2013). Whilst publishing during doctoral studies has been shown to have a significant and positive impact on future publication and citation count (Horta \& Santos, 2016), as well as increased international collaboration, visibility, and preparation for a future academic career (Thomas, West, \& Rich, 2016), writing for peer review is a great source of anxiety for doctoral students (Kamler, 2008; Jones, 2013; Mason, 2018; Pare, 2010). A certain amount of guidance on writing for publication in peer reviewed journals and appropriate journals is provided to students via doctoral supervision (Kamler, 2008; Lee \& Kamler, 2008; Nagago \& Bukovszki, 2016), however students often need to seek further help via study groups, publications, or writing coaches (McGrail et al., 2006). Problems are further exacerbated for students who are required to publish in English as their second language, as is the case for doctoral students in Hungary, who must publish their results in both their native language and in a second language (often English) in order to be awarded their PhD (Nagago \& Bukovszki, 2016). This is particularly problematic, as a significant language bias exists in English-speaking peer reviewed journals, whose articles have a better chance of being cited than those written in another language (FrancoLópez, Sanz-Valero, \& Culebras, 2016; Leon-Sarmiento, Leon-S., \& Contreras, 2007). 
As with many top-ranking journals, publication acceptance rates in the field of educational technology are not high. As of 2014, the British Journal of Educational Technology (BJET) had an acceptance rate of 9\% and Computers \& Education (CAE) 24\%, as opposed to 15\% for Higher Education, and 25\% for Higher Education Research and Development (University of Wollongong Library, 2014). Likewise, when articles are first submitted to AJET, less than 30\% are sent on to be peer reviewed (Redmond et al., 2017), and in 2015 the acceptance rate was 15\% (Heinrich, Lee, \& Henderson, 2017). Conversations within the educational technology field continue to question whether it is better to publish in open access journals (e.g., Anderson, 2018; Panker, 2018), with ranked lists of important open access articles growing in popularity (e.g., National Institute for Digital Learning, 2017). This, combined with the recent AJET editorial, prompted the author - who falls into a minority category - to question how a leading educational technology journal such as AJET is promoting the growth of scholarship, and whether the rate of international representation amongst authors is growing, given that a recent analysis of 2013-2017 keywords, abstracts, and authorship suggests that it is not (Bond \& Buntins, 2018). This study will be of particular interest to doctoral students, early career researchers, and researchers from non-English speaking backgrounds, as it will provide them with an understanding of how AJET compares to other leading educational technology journals, in what ways the editorial team have sought to support researchers and further scholarship in the field, and how receptive the journal is to international authors. It also provides an example method of critiquing journals (West \& Rich, 2012), recommendations from the literature for conducting rigorous research, and identifies areas of particular future research interest, discovered through a new application of text-mining software.

\section{Investigating research trends in educational technology}

The development of the field of educational technology has been of growing interest recently, as uncovering research trends “also reveals emerging technologies and paradigm shifts” (Baydas, Küçük, Yilmaz, Aydemir, \& Göktaş, 2015, p. 710), thereby providing guidance to educators on best practice for using technology in the classroom, as well as identifying opportunities for future research direction (Lee, Driscoll, \& Nelson, 2004), which is particularly important for early-career researchers. By revealing methodological and research trends, journal content analyses can also assist researchers to identify appropriate journals in which to publish (Baydas, et al., 2015), as opposed to researchers solely referring to citation data (West \& Rich, 2012) or an arbitrary codified list of publications (Carr-Chellman, 2006). This study seeks to build on the research foundations, laid by previous educational technology journal content analyses, which have included BJET (Latchem, 2006), Distance Education (Zawacki-Richter \& Naidu, 2016), Edutec-E Journal (Marin, Zawacki-Richter, Perez Garcias, \& Salinas, 2017), International Review of Research in Open and Distributed Learning (IRRODL) (Zawacki-Richter, Alturki, \& Aldraiweesh, 2017), and the International Journal of Educational Technology in Higher Education (Martin, Duart, Galvis, \& Zawacki-Richter, 2018), as well as comprehensive analyses of multiple educational technology journals across time (e.g., Baydas, et al., 2015; Hsu, Hung, \& Ching, 2013; Küçük, Aydemir, Yildirim, Arpacik, \& Göktaş, 2013; West \& Borup, 2014).

Whilst content analyses provide valuable overviews of the state of the field, they are focused on what has already been researched and published. For example, Baydas et al. (2015) suggested that more studies should focus on ICT-related policies, as did Latchem (2006); more mixed methods studies should be undertaken to enhance the integration of theory and practice, as did Küçük et al. (2013); and that the "methodological tendencies of a journal should be considered carefully during the selection process” (Baydas et al., 2015, p. 723). Whilst this is certainly helpful to early-career researchers, and provides an idea of where research gaps exist, this does not adequately capture future directions for the state of the field, the identification of which is necessary to catapult doctoral students into valuable and cutting-edge work. Such innovative work is more likely to make a significant contribution to the field (Henderson, Heinrich, \& Lee, 2016), thereby increasing the chance of publication in a quality peer reviewed journal such as AJET (Redmond et al., 2017).

Therefore, this study seeks to answer the research questions:

1. To what extent has AJET reflected a focus on Asia-Pacific scholarship from 2013 to 2017?

2. How has AJET contributed to furthering scholarship in the field of educational technology?

3. What research topics and issues have been identified by researchers as important for future research, and published in AJET from 2013 to 2017? 


\section{The sample: Australasian Journal of Educational Technology (AJET)}

AJET was established in 1985 and is published six times a year by the Australasian Society for Computers in Learning in Tertiary Education (ASCILITE), including occasional special issues (Bond \& Buntins, 2018). It is indexed in many international indexes, including the Social Science Citation Index (SSCI), having become an online-only, open access journal in 2008, following a merger with the e-Journal of Instructional Science and Technology and the International Journal of Educational Technology in 2007 (Australasian Journal of Educational Technology [AJET], 2017a). Following this move, editorial policy focused on expanding its reach and raising the profile of non-English speaking researchers, particularly from the AsiaPacific region (Atkinson \& McLoughlin, 2009; Hadlock et al., 2014). Editorials began highlighting topics in 2013, specifically written to assist authors better understand the publication process and thereby potentially strengthen the quality of research (Bennett, Kennedy, \& Dalgarno, 2013). This was also the year that AJET altered its focus to higher education only research (Dalgarno, Bennett, \& Henderson, 2015). This research includes all articles from 2013 to $2017(n=256)$ (Table 1), in order to compare data from 2003 to 2012 in the AJET analysis by Hadlock et al. (2014), as well as to ascertain the effect that the shift in editorial focus had on authorship and journal impact.

Table 1

Annual numbers of issues and articles in AJET (2013-2017)

\begin{tabular}{cccccc}
\hline Year & Issues & Articles & Year & Issues & Articles \\
\hline 2013 & 6 & 60 & 2016 & 6 & 45 \\
2014 & 6 & 48 & 2017 & 6 & 57 \\
2015 & 6 & 46 & & & 256 \\
Total & & & & & 256 \\
\hline
\end{tabular}

\section{AJET in previous bibliographic studies}

Research published in AJET in 2013-2017 has become more student-centred (Bond \& Buntins, 2018), focusing in particular on teacher knowledge and skill development to strengthen teaching and learning, as well as on collaborative learning in online environments, echoing a previous analysis of AJET (McDonald \& Loke, 2016) and research in the wider educational technology field (e.g., Marin, Duart, Galvis, \& ZawackiRichter, 2018; Zawacki-Richter, et al., 2017; Zawacki-Richter \& Latchem, 2018). AJET publications during this period used a relatively even mix of inferential, interpretative, and combined methods (Bond \& Buntins, 2018), showing less methodological bias than in other educational technology journals (Perez-Sanagustin, et al., 2017; Twining, Heller, Nussbaum, \& Tsai, 2017). Whilst the high frequency of the keywords "foreign countries" continued between 2013 and 2017, there was a drop in the percentage of articles that used it, suggesting that there was less international representation in AJET authorship, therefore this will be analysed in the current article.

Aside from the analyses by Bond and Buntins (2018), McDonald and Loke (2016) and Hadlock et al. (2014), AJET editors also provide yearly bibliometric analyses (e.g., Dalgarno, Heinrich, \& Henderson, 2016), which provide submission and review statistics, publication summaries, the most downloaded articles, and citation information. Article submissions continue to grow, which has meant a larger number of rejections at both stages of the review process (Heinrich, Lee, \& Henderson, 2017). The Google $h$-index and the 5-year impact factor have both grown in the past 2 years (Bond \& Buntins, 2018); however citations alone are not enough to measure a journal's quality (Dalgarno, Kennedy, \& Bennett, 2014). Using impact factors to evaluate educational research is problematic due to bias, skewing of metrics, editorial policies, and methodological preferences (Lavie, 2009; Ouimet, Bedard, \& Gelineau, 2011; Saxena, Thawani, Chakarbarty, \& Gharpure, 2013; Staller, 2017), therefore this research seeks to explore AJET's impact and support of scholars and scholarship beyond metrics alone (West \& Rich, 2012).

\section{Method}

This study was conducted using both qualitative and quantitative methods, and seeks to build upon the existing body of educational technology journal research, by exploring how computer-assisted content analysis using the text-mining software Leximancer (Zawacki-Richter \& Latchem, 2018) can be used to analyse other article and journal components, aside from titles and abstracts. Whilst titles and abstracts are "lexically dense and focus on the core issues presented in articles" (Cretchley, Rooney, \& Galois, 2010, p. 
319), they are limited in size and often do not go into sufficient detail about future research directions. This research will also compare the results of the 2003 to 2012 analysis of AJET (Hadlock et al., 2014) with data from 2013 to 2017, in order to ascertain whether changes to the approach of editorials in 2013 (Bennett, Kennedy, \& Dalgarno, 2013) have resulted in any substantial changes of international representation.

Whilst it is recognised that this study seeks to answer the research questions through one English-speaking lens, this journal is not only "the premier journal in Australasia which publishes manuscripts related to technology enhanced learning and teaching in post-secondary education settings” (Redmond, et al., 2017, p. i), but also a highly ranked and respected journal internationally (Thomson Reuters, 2017). In 2017, AJET published 2 articles that featured in the top 10 educational technology open access articles for the year (National Institute for Digital Learning, 2017).

\section{Authorship analysis}

In order to answer research question 1: To what extent has AJET reflected a focus on Asia-Pacific scholarship from 2013 to 2017?, all country data for authors were extracted from the Web of Science database and analysed by the software R-Package bibliometrix (Aria \& Cuccurullo, 2017). However, it was realised that the data was incomplete, only showing countries from first authors. Therefore, all articles from 2013 to 2017 were checked manually on the AJET website and on the records of Web of Knowledge, extracting the number of authors and articles per country, per year, in order to gauge how widespread the international scope of the journal actually is (Atkinson \& McLoughlin, 2009; Hadlock et al., 2014).

\section{Evaluation of rigour, impact, and prestige}

Whilst citation analyses are "commonly used to explore the intellectual structure of a given discipline” (Liu \& Wang, 2005, p. 308), interpreting educational research quality using impact factors alone is problematic (Lavie, 2009; Ouimet, et al., 2011; Saxena, et al., 2013; Staller, 2017), particularly given the issues in assessing research quality in Australia (e.g., Smith, 2014). Therefore, in order to explore how AJET has furthered scholarship in the field (research question two), an analysis of AJET's rigour, impact and prestige was undertaken, following the framework by West \& Rich (2012).

\section{Rigour}

Journals set the parameters for format, length, style, methodology, and focus, thereby shaping the state of research published in a field (Hardré \& Mortensen, 2013). In order to establish a journal's rigour, it is important to consider how high publication standards are, and whether research is judged critically on its merits prior to acceptance (West \& Rich, 2012). Therefore, an analysis of AJET's acceptance rate, including time to publication, peer review policy, and the number of reviewers was undertaken.

\section{Impact}

In order to evaluate the impact of a journal, it is important to consider its circulation, including availability on the internet, as well as any indication that the journal has had an impact on other scholars in the field (West \& Rich, 2012). Therefore, AJET's publication rate and open access policy were reviewed, and a citation and journal metric analysis undertaken (Bond \& Buntins, 2018), which helps show how influential the journal has been on other scholars. The citation analysis of AJET and other leading educational technology journals (Dalgarno, Kennedy, \& Bennett, 2014) was conducted using Thomas Reuters Journal Citation Reports ${ }^{\circledR}$, the Google Scholar $h$-index and the freeware Publish or Perish (Harzing, 2007), in order to triangulate citation data (West \& Rich, 2012).

\section{Prestige}

The prestige of a journal can be determined by considering whether other academics thinks the journal is prestigious, whether it is sponsored and supported by a large national or international professional organisation, and whether the editor and editorial board is well-known and respected (West \& Rich, 2012). Therefore, the analysis of open access journals by Perkins and Lowenthal (2016) was considered, and a citation analysis was conducted for members of the editorial board.

\section{Computer-assisted content analysis using Leximancer}


In order to answer research questions 2: How has AJET contributed to furthering scholarship in the field of educational technology?, and 3: What research topics and issues have been identified by researchers as important for future research, and published in AJET from 2013 to 2017?, a content analysis was undertaken using the text-mining software Leximancer. The software reduces time and cost, as well as limiting human bias (Krippendorff, 2013), and is considered to be an appropriate method by which to map out a research domain (Fisk, Cherney, \& Hornsey, 2012). In order to detect future research areas, as identified by researchers published in AJET, all articles from 2013 to $2017(n=256)$ were hand searched for appropriate sections containing recommendations. To the author's knowledge, this method has not been used in prior research. In some cases, these sections were labelled Conclusion and Future Direction (e.g., Chai, Ng, Li, Hong, \& Koh, 2013), Summary and Recommendations (e.g., Pegrum, Howitt, \& Striepe, 2013), or Summary and Outlook (e.g., Thalmann, 2014). In order to gain an understanding of how AJET furthers scholarship in the field, all editorials were extracted $(n=28)$, excluding special issues and descriptions of issues. Both data subsets were then uploaded into Leximancer and the software automatically identified significant concepts and themes, producing concept maps that show frequency and connectedness (Smith \& Humphreys, 2006), which were then analysed by the author.

\section{Results and discussion}

\section{Authorship analysis}

Whilst there appeared to be reduced international representation within AJET from 2013 to 2017 (Bond \& Buntins, 2018), as opposed to 2003 to 2012, an analysis of articles from 2008 to $2012(n=336)$ revealed that this was not the case (Table 2), with very Australian-centric authorship until 2011, and Oceanian research representing $50 \%$ of articles published in those 5 years. Authors hailed from 37 different countries, and whilst this does confirm the findings of Hadlock, et al. (2014) that AJET has an international outlook, the next highest region represented was Asia with 33\%, followed by North America with $10 \%$.

An analysis of the geographic representation of 2013 to 2017 articles revealed that authors hailed from 36 different countries (the full table is available from http://www.researchgate.net/Melissa_Bond2). When viewed as percentage of articles per region, Asia-Pacific represent $78 \%$ of all articles, with even distribution between the two. There were no authors from South America, and very few from the Middle East or Africa. This echoes the findings of authorship in CAE by Perez-Sanagustin, et al. (2017), and is in stark contrast to country representation found in IRRODL (Zawacki-Richter et al., 2017), another open access journal, where 64 countries were represented by first authors alone. This was, however, over a period of 15 years (20002015), in contrast to the current AJET analysis across 5 years. Analysing the authorship of all articles published in 2013 revealed that 28 different countries were represented in IRRODL across authors from 71 articles, as opposed to 12 countries in AJET across 60 articles. Whilst this number increased to 20 different countries in 2017, and "any journal's significance has a regional component” (Perkins \& Lowenthal, 2016, p. 33), this is an indication that more effort could be made to attract authors from a wider variety of cultural contexts, given the importance of context within research (Bennett, Dalgarno, Kennedy, \& Henderson, 2014; Perez-Sanagustin et al., 2017).

Table 2

Number of authors per region

\begin{tabular}{lcccc}
\hline \multirow{2}{*}{ Region } & \multicolumn{2}{c}{$2008-2012$} & \multicolumn{2}{c}{$2013-2017$} \\
& No. of papers & \% of papers & No. of papers & \% of papers \\
\hline Oceania & 167 & $50 \%$ & 100 & $39 \%$ \\
Asia & 111 & $33 \%$ & 99 & $39 \%$ \\
North America & 32 & $10 \%$ & 38 & $15 \%$ \\
Europe & 28 & $8 \%$ & 31 & $12 \%$ \\
Middle East & 16 & $5 \%$ & 11 & $4 \%$ \\
Africa & 10 & $3 \%$ & 6 & $2 \%$ \\
South America & 2 & $1 \%$ & 0 & $0 \%$ \\
\hline
\end{tabular}

When the top six represented countries are viewed across time (Figure 1), a more balanced contribution is seen in 2015, where authors from Taiwan were more prolific than Australian authors; a trend seen across a number of educational technology journals (Hsu, Hung, \& Ching, 2013). Interestingly, the number of Taiwanese authors have since decreased, to be replaced by a growing number of American authors. 


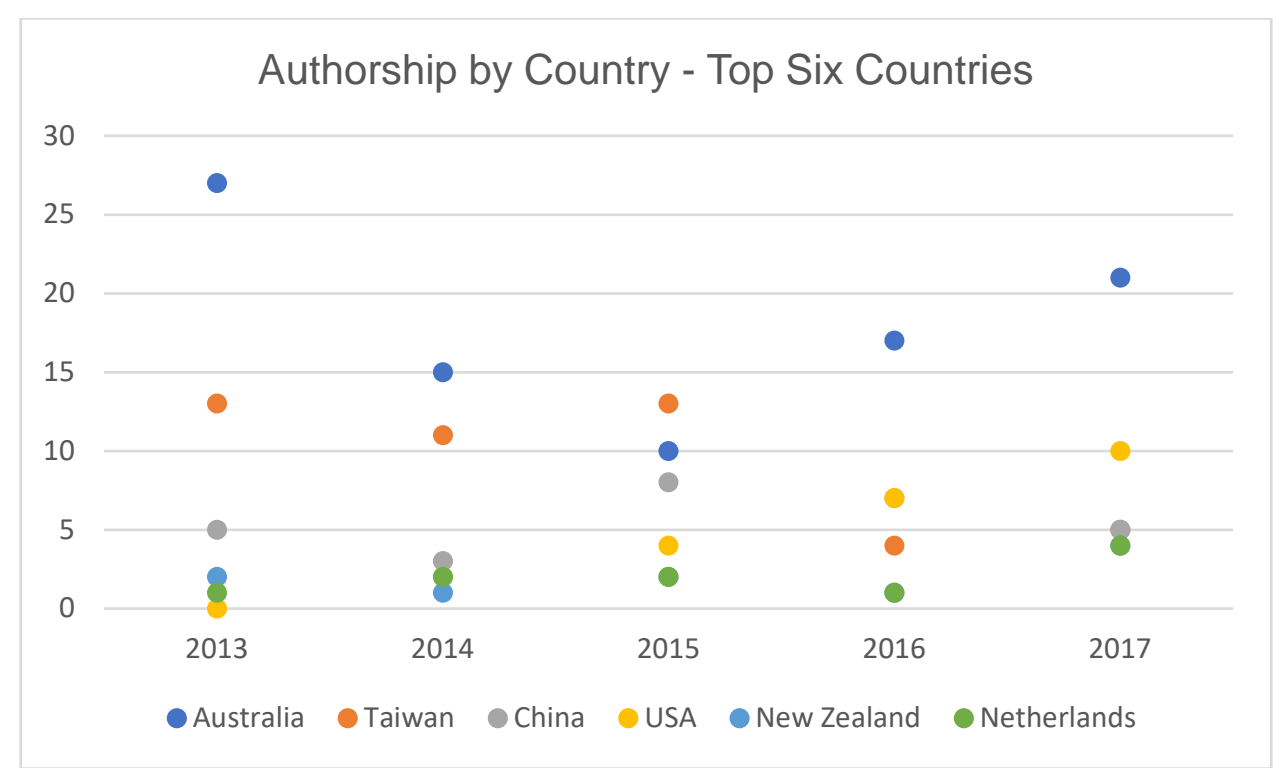

Figure 1. Six most represented countries by authorship, 2013-2017

\section{Evaluation of rigour, impact, and prestige}

\section{Rigour}

AJET has a two-stage review process, with papers needing to pass editorial review prior to forwarding for double blind peer reviewing (Australasian Journal of Educational Technology [AJET], 2017b). AJET reviewers must be research active and engaged within a related field, as well as be experienced with giving and receiving peer reviews. At least two voluntary non-blind editor reviewers and two voluntary blind peer reviewers evaluate an article before it is accepted for publication (Heinrich, Henderson, \& Redmond, 2017). In 2015, 67\% of articles submitted at the editorial stage, and half of the articles subsequently peer reviewed, were declined, with only 15\% of submissions subsequently published (Heinrich, Lee, \& Henderson, 2017). This places AJET within the average of educational technology journal acceptance rates (University of Wollongong Library, 2014), and adhering to high quality reviewing procedures (De Silva \& Vance, 2017), thereby achieving a high level of rigour.

\section{Time to publication}

Based on 2016/2017 data provided by AJET editors, initial screening of submitted articles is under one month, which is comparable to BJET at 2 weeks, although the average time to first review decision and final acceptance is slightly higher than other similar journals (Table 3). Given the rigour of the review process, however, this should not overly dissuade submission to AJET.

Table 3

Average time to first review decision and final acceptance

\begin{tabular}{lcc}
\hline Journal & Time to first decision & Time to final acceptance \\
\hline AJET* & 4 months & 7 months \\
BJET & 2 months & 6 months \\
CAE & 4 months & 5 months \\
IRRODL* & $2-3$ months & 6 months \\
\hline
\end{tabular}

* open access

Impact

AJET is published six times per year under an open access policy that does not charge authors or readers, enabling "a greater global exchange of knowledge” (AJET, 2017b), appreciated by educational technology academics (Perkins \& Lowenthal, 2016). Open access articles are more likely to be quickly and highly cited (Zawacki-Richter, Anderson, \& Tuncay, 2010), which helps grow a researcher's profile. The citation analysis (see Bond \& Buntins, 2018) revealed that AJET's 5-year impact factor has remained relatively stable, given 
the introduction of new journals with 5-year impact factors (e.g., Learning Media and Technology). AJET has a 5-year impact factor of 1.460 and is ranked 151/235 of education and educational research journals. The Google $h$-index has shown growth since 2014, placing it above journals with a higher 5-year impact factor, as the $h$-index also considers citations within publications outside the SSCI (Hirsch, 2005). This is an example of the importance in considering a range of factors when considering where to publish (West \& Rich, 2012).

\section{Prestige}

AJET is the journal of ASCILITE, which is a globally recognised (ASCILITE, 2014) professional association, and in a survey of 323 international educational technology scholars (Perkins \& Lowenthal, 2016), AJET was ranked the second most influential open access journal. AJET also featured 2 articles in the top 10 list of open access articles in 2017 (National Institute for Digital Learning, 2017).

Hirsch (2005, p. 16571) suggests that a $h$-index over 20, after 20 years of academic activity, would indicate a successful scientist, a $h$-index over 40 would indicate an outstanding scientist, and a $h$-index over 60 would indicate a truly unique individual. AJET has two lead editors and 18 editorial board members. Of these, eight are recognised as successful, five as outstanding, and one as unique according to Google Scholar. However, if one uses the $g$-index instead (Egghe, 2006), which gives more weight to highly cited articles and is available through the Publish or Perish software (Harzing, 2007), all except one editorial board member is well and truly above 20. Therefore, AJET has an extremely experienced and well-respected board of editors. The evaluation of AJET quality via the three factors of rigour, impact, and prestige are shown in Table 4.

Table 4

Evaluation of AJET quality

\begin{tabular}{|c|c|c|}
\hline Rigour & Impact & Prestige \\
\hline $\begin{array}{ll}\text { - } & 15 \% \text { acceptance rate. } \\
\text { - } & \text { Two stage review process. } \\
& \text { Double blind peer } \\
\text { - } & \text { reviewed. } \\
& \text { Reviewers must be research } \\
\text { active and have peer review } \\
\text { experience. } \\
\text { Less than } 1 \text { month for } \\
\text { initial screening of } \\
\text { - } \quad \text { Abmissions. } \\
\text { Acceptance time lengthy. }\end{array}$ & $\begin{array}{ll}\text { - } & \text { Published } 6 \text { times per year. } \\
\text { - } & \text { Open access - no publishing } \\
\text { or reading fee. } \\
\text { - } \quad \begin{array}{l}\text { Ranked in the top } 18 \\
\text { educational technology }\end{array} \\
\text { journals. } \\
\text { 151/235 in education and } \\
\text { educational research. }\end{array}$ & 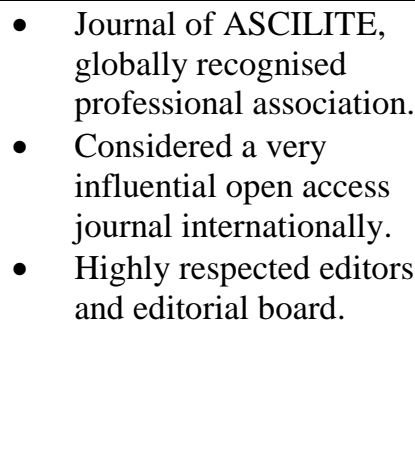 \\
\hline
\end{tabular}

\section{Analysis of future research trends in AJET (2013 to 2017)}

The content analysis of future research trends in AJET (Figure 2) confirms the keyword and abstract analysis by Bond \& Buntins (2018) that student learning and teacher development are in focus, rather than technology. The thematic summary reveals that learning has the most direct mentions within the text with 1,197 (100\% relative count), followed by students (98\%), study (93\%), teachers (56\%), learners (17\%), feedback (12\%), content $(12 \%)$, information $(11 \%)$ and access $(7 \%)$. There are five key areas of focus identified for future research: (1) the development of teachers' technology skills and TPACK (teachers-education-developmenttechnology-teaching-need-skills and teachers/pre-service-knowledge-practices/content); (2) the development of quality content (resources-effective-support-activities-learning-environment); (3) student accessibility to learning (access-time-student-learning-mobile), (4) the impact of learning environments on cognition (cognitive-learners-system-participants-social-learning-environment); and (5) the role of feedback (feedback-students-online-communication), which was also found to be prevalent in CAE (Zawacki-Richter \& Latchem, 2018). 


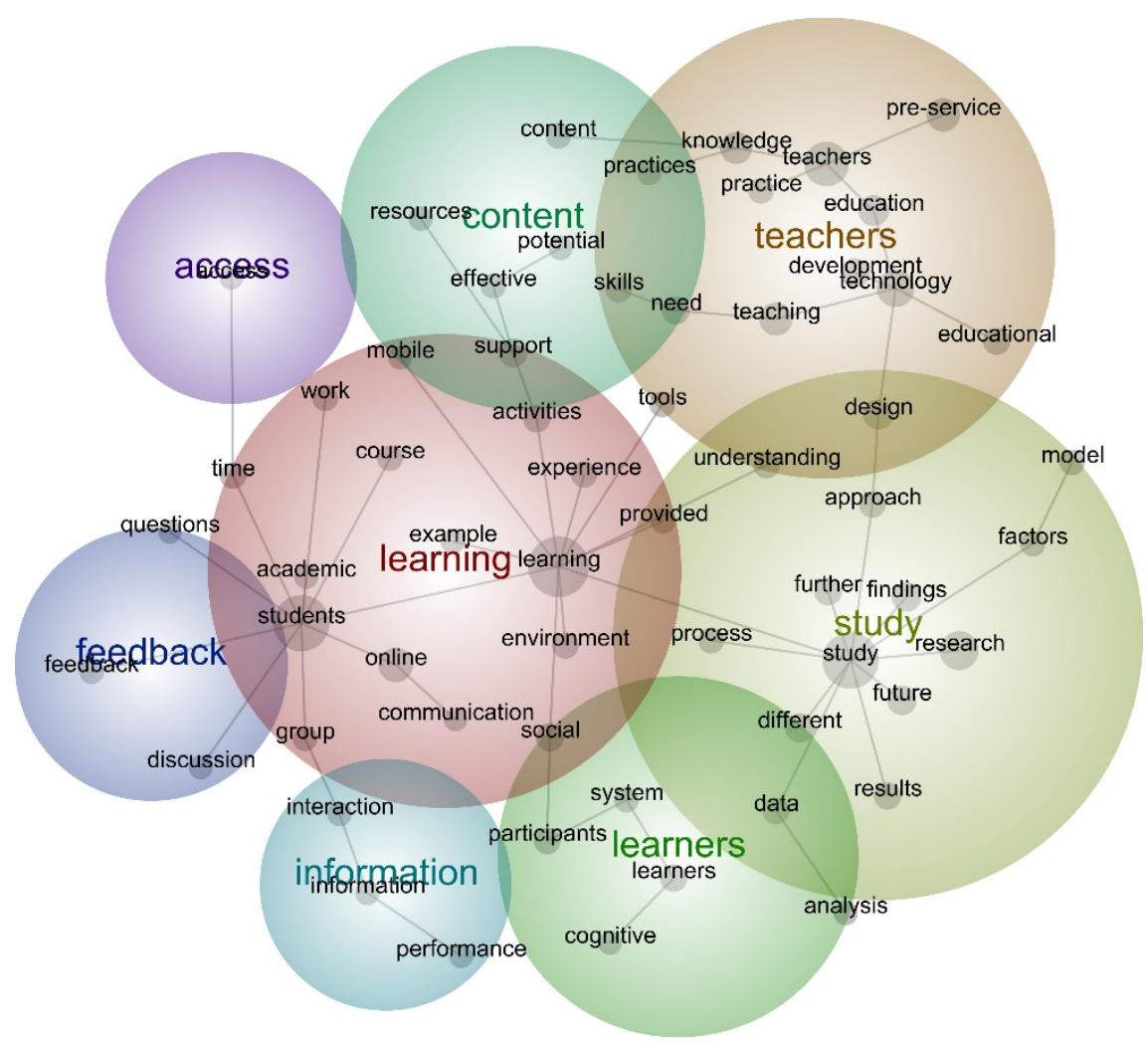

Figure 2. Concept map of future research trends in AJET (2013-2017; $n=256)$

The following is a list of areas for future research in the field of educational technology, as suggested by authors published in AJET during 2017. These could be possible lines of research for doctoral students, as they reflect gaps in the literature, which could provide more chances of getting their research published.

In-service and pre-service teacher development

- Exploration of teacher education instructor use of technology, in order to gain context of pre-service teacher use (e.g., Batane \& Ngwako, 2017).

- Development of computational thinking modules for use in content-specific pre-service teacher courses (e.g., Mouza, Yang, Pan, Ozden, \& Pollock, 2017).

- Longitudinal studies that track the development of TPACK across time (e.g., Valtonen, Sointu, Kukkonen, Lambert, \& Makitalo-Siegl, 2017).

Development of quality content

- Analyse how reusable learning objects impact on blended learning experiences (e.g., Koh, 2017).

- Use log trace data to investigate how teachers rate the quality or usefulness of resources in online public databases (e.g., Poitras, Doleck, Huang, Li, \& Lajoie, 2017).

- Investigate the effects of differentiated learning materials on student outcomes in the flipped learning classroom (e.g., Shih \& Tsai, 2017).

\section{Student accessibility to learning}

- Mixed method studies that focus on how students perceive learning with educational technology (e.g., Chai, Tan, Deng, \& Koh, 2017).

- Student engagement with and preference for multi-purpose or sole-purpose higher education apps (e.g., Pechenkina, 2017). 
Learning environments and cognition

- Use of neuro-imaging techniques to measure cognitive load in AR learning environments (e.g., K.H. Cheng, 2017).

- Investigate how learning management systems can be used to enhance student learning processes and sense of connectedness within cross-institutional studies using mixed methods (e.g., Sadowski, Pediaditis, \& Townsend, 2017).

The role of feedback

- Analyse the impact of automatic classification technology providing immediate feedback on student writing (e.g., G. Cheng, 2017).

- Explore the use of student-facing learning analytics and how best to assist students to understand them (e.g., Kitto, Lupton, Davis, \& Waters, 2017).

\section{Editorial content analysis}

In 2013 (from issue 3 onwards), the editors changed their editorial approach, to one that focuses on a "current issue in educational technology or reflect[s] on aspects of publishing AJET [that they] would like to draw to the attention of ... readers” (Bennett, Kennedy, \& Dalgarno, 2013, p. i). This places them among an increasing number of journals who are seeking to provide advice to researchers, in order to boost submission quality (e.g., American Journal of Nursing, 2017; Twining et al., 2017). The concept map in Figure 3 depicts the major areas covered within these editorials, which shows that there was a particular concern about the quality of research being sent to AJET for potential publication (research-educational-quality-studyeducational-quality-issues-educational-quality), as well as challenges in the field (methods-studyeducational-challenges-field). In order to help improve the overall quality of publications, AJET editors sought to guide researchers and potential authors by outlining important considerations when conducting research, in order to move scholarship forward and "advance the field of educational technology" (Bennett, 2015, p. i). Editorials have particularly stressed the need for authors to place their research within the field, clearly identifying its significance and valuable contribution to the existing body of work (Bennett, Dalgarno, \& Kennedy, 2013; Bennett, Kennedy, \& Dalgarno, 2013; Henderson et al., 2016).

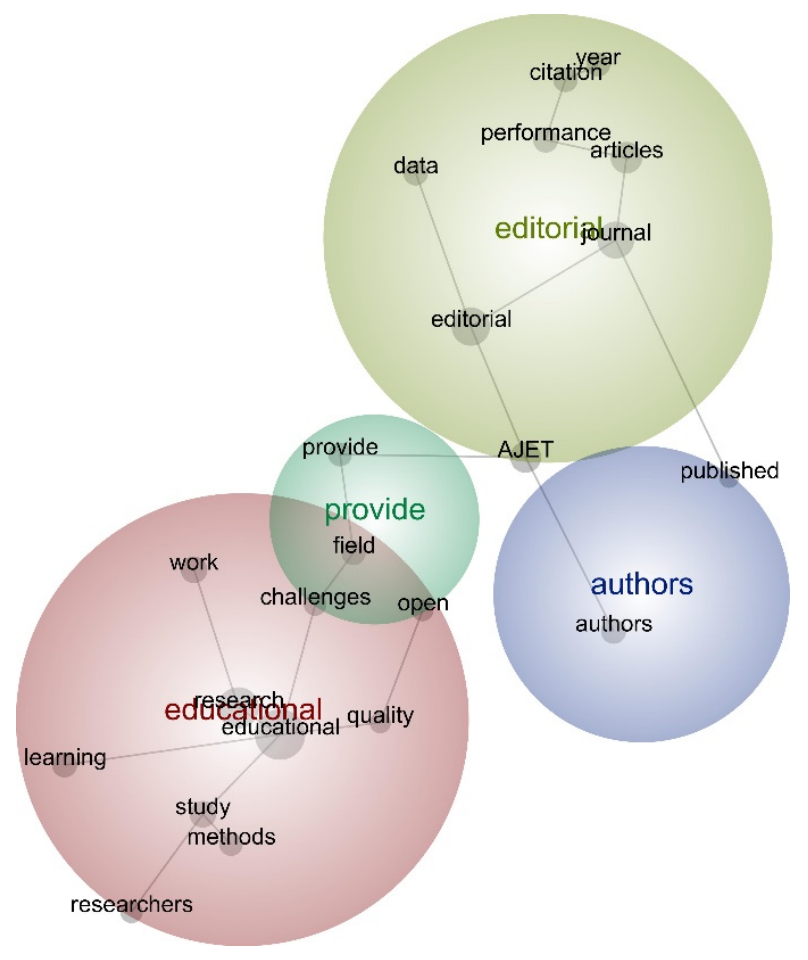

Figure 3. Concept map of AJET Editorials, without Special Issues (Issue 3 2013-2017; $n=24$ )

Aside from providing regular bibliometric analyses of AJET's performance (e.g., Dalgarno, Heinrich, \& Henderson, 2016; Heinrich, Lee, \& Henderson, 2017) (articles, performance, citation), the editors also 
provided advice on how Google Scholar Journal Metrics (Dalgarno, Kennedy, \& Bennett, 2014) and open access publishing works (Dalgarno, Bennett, \& Kennedy, 2014) (open, quality, educational, research). Another way of supporting authors has been the introduction of early release articles; making articles available online that have been accepted for publication, which have been copyedited and typeset but which have not yet been published within an issue (Henderson, Bennett, \& Dalgarno, 2015). This, in conjunction with advice for best practice in conducting literature searches (Dalgarno, Bennett, Henderson, \& Kennedy, 2014), case studies (Bennett et al., 2014) and mixed methods research (Bennett, Dalgarno, \& Henderson, 2015), as well as a call for researchers to maintain a wider appreciation of ethics (Heinrich, Henderson, \& Lee, 2016), places AJET as a transparent journal, committed to furthering scholarship in the field of educational technology.

\section{Limitations}

AJET is one English-speaking lens through which to view the field of educational technology, and what is published in any one journal is subject to editorial, reviewer and funding influences (Goldenberg \& Griegl, 1991). However, by using the framework of rigour, impact, and prestige (West \& Rich, 2012), the journal was critically analysed by itself and in comparison to other educational technology journals. It is also acknowledged that, whilst Leximancer limits human bias (Krippendorff, 2013), the results must be interpreted through researcher "analytical sensitivity and judgement” (Harwood, Gapp, \& Stewart, 2015, p. 1041).

\section{Future research}

Future research could include applying the content analysis method employed here to other educational technology journals, in order to gain a more rounded understanding of future directions for the state of the field, as well as to gauge the degree to which research published in such journals contributes to the resolution of significant educational problems. It would also be interesting to investigate how educational technology journals use social media to spread awareness of editorial and article content, and how often doctoral students access editorial advice to inform publishing decisions. Likewise, it would be interesting to analyse the percentage of papers in AJET that are authored by doctoral students, those written by various ranks of academics, and those authored by practitioners, which was unfortunately beyond the scope of this paper. It would be profoundly helpful to collate advice given by journals in one article or repository, perhaps by means of a systematic review, to allow easy access to those who need it. Further research is also planned into the international collaboration of educational technology researchers, given the results from the geographic authorship analysis and the authorship analysis by Bond and Buntins (2018).

\section{Recommendations for doctoral students}

1. Consider the list of identified trends above if choosing a new area to research.

2. Read journal editorials regularly and stay abreast of trends and research gaps by paying close attention to the Future Research section of articles.

3. Ensure careful choice of keywords when publishing.

4. Citing a number of articles from the journal in which you are publishing can show that you have an awareness of research that is of interest to that journal's readership (Dalgarno, Kennedy, \& Bennett, 2014).

5. Undertake rigorous mixed methods research (Bennett, Dalgarno, \& Henderson, 2015; Poth, 2018) and carefully consider the context in which you are researching (Bennett et al., 2014; PerezSanagustin et al., 2017).

6. Use the journal evaluation framework by West and Rich (2012) and consider a range of data, rather than relying on one metric, when deciding in which journals to publish.

\section{Conclusion}

The analysis of articles published in AJET from 2013 to 2017 has revealed a number of future research trends, including the development of teacher technology skills, student accessibility to learning and the role of feedback in student learning. These trends were uncovered by using text-mining software Leximancer in a unique way, and it would be interesting to reflect upon these results in five years, to see whether these lines of research were investigated. Whilst AJET has been focused on promoting Asia-Pacific researchers in 
particular (Atkinson \& McLoughlin, 2009; Hadlock et al., 2014), a review of geographic authorship and editorial policy has revealed that authors from other parts of the world are equally considered, but are underrepresented. ESL researchers and doctoral students are strongly encouraged to consult the range of publishing advice contained in regular editorials, in order to improve submission quality (Redmond et al., 2017), as well as consult the list of recommendations provided in this article. In order to further scholarship and highlight publishing advice, editors could use Twitter (e.g., @AJET_eds) to tweet editorials, using hashtags relevant to doctoral students (e.g., \#phdchat \#phdforum \#PhD \#phdlife \#AcWri \#edtech). Overall, an exploration according to the rigour, impact and prestige framework (West \& Rich, 2012) has revealed that AJET is an attractive open access journal in which to publish, which has demonstrated an ongoing commitment to further scholarship in the field of educational technology.

\section{Acknowledgements}

Sincere thanks goes to Katja Buntins, as well as to my Oldenburg colleagues, for their assistance and advice. A heartfelt thanks also to editor Judi Harris and the anonymous peer reviewers for their thoughtful critique and guidance.

\section{References}

Anderson, T. (2018). More on distance education journal rankings [Blog post]. Retrieved from https://virtualcanuck.ca/2018/03/08/more-on-distance-education-journal-rankings/

American Journal of Nursing (2017). Writing for publication: Step by step. Retrieved from https://journals.lww.com/ajnonline/pages/collectiondetails.aspx?TopicalCollectionId=39

Aria, M., \& Cuccurullo, C. (2017). bibliometrix: An R-tool for comprehensive science mapping analysis. Journal of Informetrics, 11(4), 959-997. https://doi.org/10.1016/j.joi.2017.08.007

ASCILITE (2014). About ASCILITE. Retrieved from http://ascilite.org/about-ascilite/

Atkinson, R., \& McLoughlin, C. (2009). Announcing AJET's new editorial board. Australasian Journal of Educational Technology, 25(2), iii-vi.

Australasian Journal of Educational Technology (2017a). Journal history. Retrieved from https://ajet.org.au/index.php/AJET/about/history

Australasian Journal of Educational Technology (2017b). Editorial policies. Retrieved from https://ajet.org.au/index.php/AJET/about/editorialPolicies\#focusAndScope

Badley, G. (2009). Publish and be doctor-rated: The PhD by published work. Quality Assurance in Education, 17(4), 331-342. http://doi.org/10.1108/09684880910992313

Batane, T., \& Ngwako, A. (2017). Technology use by pre-service teachers during teaching practice: Are new teachers embracing technology right away in their first teaching experience? Australasian Journal of Educational Technology, 33(1), 48-61. https://doi.org/10.14742/ajet.2299

Baydas, O., Küçük, S., Yilmaz, R., Aydemir, M., \& Göktaş, Y. (2015). Educational technology research trends from 2002 to 2014. Scientometrics, 105(1), 709-725. https://doi.org/10.1007/s11192-015-1693-4

Bennett, S. (2015). Editorial. Australasian Journal of Educational Technology, 31(6), i-ii. https://ajet.org.au/index.php/AJET/article/view/2947/1332

Bennett, S., Dalgarno, B., \& Henderson, M. (2015). Editorial. Australasian Journal of Educational Technology, 31(3), i-ii. https://doi.org/10.14742/ajet.2804

Bennett, S., Dalgarno, B., \& Kennedy, G. (2013). Editorial. Australasian Journal of Educational Technology, 29(5), i-ii. https://doi.org/10.14742/ajet.1503

Bennett, S., Dalgarno, B., Kennedy, G., \& Henderson, M. (2014). Editorial. Australasian Journal of Educational Technology, 30(5), i-ii. https://doi.org/10.14742/ajet.2231

Bennett, S., Kennedy, G., \& Dalgarno, B. (2013). Editorial. Australasian Journal of Educational Technology, 29(3), i-ii. https://doi.org/10.14742/ajet.993

Bond, M., \& Buntins, K. (2018). An analysis of the Australasian Journal of Educational Technology 20132017. Australasian Journal of Educational Technology, 34(4), 168-183. https://doi.org/10.14742/ajet.4359

Carr-Chellman, A. (2006). Where do educational technologists really publish? An examination of successful emerging scholars’ publication outlets. British Journal of Educational Technology, 37(1), 515. https://doi.org/10.1111/j.1467-8535.2005.00522.X

Chai, C., Ng, E., Li, W., Hong, H.-Y., \& Koh, J. (2013). Validating and modelling technological pedagogical content knowledge framework among Asian preservice teachers. Australasian Journal of Educational Technology, 29(1), 41-53. https://doi.org/10.14742/ajet.174 
Chai, C., Tan, L., Deng, F., \& Koh, J. (2017). Examining pre-service teachers' design capacities for webbased 21st century new culture of learning. Australasian Journal of Educational Technology, 33(2), 129-142. https://doi.org/10.14742/ajet.3013

Cheng, G. (2017). Towards an automatic classification system for supporting the development of critical reflective skills in L2 learning. Australasian Journal of Educational Technology, 33(4), 1-21. https://doi.org/10.14742/ajet.3029

Cheng, K.-H. (2017). Reading an augmented reality book: An exploration of learners' cognitive load, motivation, and attitudes. Australasian Journal of Educational Technology, 33(4), 53-69. https://doi.org/10.14742/ajet.2820

Cretchley, J., Rooney, D., \& Galois, C. (2010). Mapping a 40-year history with Leximancer: Themes and concepts in the Journal of Cross-Cultural Psychology. Journal of Cross-Cultural Psychology, 41(3), 318-328. https://doi.org/10.1177/0022022110366105

Dalgarno, B., Bennett, S., \& Henderson, M. (2015). Editorial. Australasian Journal of Educational Technology, 31(2), i-iii. https://doi.org/10.14742/ajet.2690

Dalgarno, B., Bennett, S., Henderson, M., \& Kennedy, G. (2014). Editorial. Australasian Journal of Educational Technology, 30(6), i-ii. http://dx.doi.org/10.14742/ajet.2357

Dalgarno, B., Bennet, S., \& Kennedy, G. (2014). Editorial. Australasian Journal of Educational Technology, 30(2), i-iii. https://doi.org/10.14742/ajet.1888

Dalgarno, B., Heinrich, E., \& Henderson, M. (2016). Editorial. Australasian Journal of Educational Technology, 32(1), i-iv. https://doi.org/10.14742/ajet.3095

Dalgarno, B., Kennedy, G., \& Bennett, S. (2014). Editorial. Australasian Journal of Educational Technology, 30(3), i-iv. https://doi.org/10.14742/ajet.2029

De Silva, P., \& Vance, C. (2017). Preserving the quality of scientific research: Peer review of research articles. In P. De Silva, \& C. Vance (Eds.), Scientific scholarly communication. Fascinating life sciences. (pp. 73-99). Cham: Springer. https://doi.org/10.1007/978-3-319-50627-2_6

Egghe, L. (2006). Theory and practise of the g-index. Scientometrics, 69(1), 131-152. https://doi.org/10.1007/s11192-006-0144-7

Fiala, J., Mares, J., \& Sestak, J. (2017). Reflections on how to evaluate the professional value of scientific papers and their corresponding citations. Scientometrics, 112(1), 697-709. https://doi.org/10.1007/s11192-017-2334-x

Fisk, K., Cherney, A., \& Hornsey, S. A. (2012). Using computer-aided content analysis to map a research domain: A case study of institutional legitimacy in postconflict East Timor. SAGE Open, 2(4), 1-15. https://doi.org/10.1177/2158244012467788

Franco-López, A., Sanz-Valero, J., \& Culebras, J. (2016). Publicar en castellano, o en cualquier otro idioma que no sea inglés, negativo para el factor de impacto y citaciones. Journal of Negative and No Positive Results, 1(2), 65-70. https://doi.org/10.19230/jonnpr.2016.1.2.1005

Goldenberg, S., \& Griegl, F. (1991). Gender, science and methodological preferences. Social Science Information, 30(3), 429-443. https://doi.org/10.1177/053901891030003003

Hadlock, C., Clegg, J., Hickman, G., Huyett, S., Hensen, H., \& West, R. (2014). An analysis of the Austalasian Journal of Educational Technology 2003-2012. Australasian Journal of Educational Technology, 30(4), ii-ix. https://doi.org/10.14742/ajet.2126

Hardré, P., \& Mortensen, C. (2013). Education journals: Two decades of change and implications for the field. Journal of the Association for Information Science and Technology, 65(1), 188-200. https://doi.org/10.1002/asi.22947

Harwood, I., Gapp, R., \& Stewart, H. (2015). Cross-check for completeness: Exploring a novel use of Leximancer in a grounded theory study. The Qualitative Report, 20(7), 1029-1045. Retrieved from http://nsuworks.nova.edu/tqr/vol20/iss7/5

Harzing, A. (2007). Publish or Perish. Retrieved from http://www.harzing.com/pop.htm

Heinrich, E., Henderson, M., \& Lee, C. (2016). Editorial. A question of ethics. Australasian Journal of Educational Technology, 32(5). https://doi.org/10.14742/ajet.3478

Heinrich, E., Henderson, M., \& Redmond, P. (2017). The endeavour of academic publishing. Australasian Journal of Educational Technology, 33(4), i-iii. https://doi.org/10.14742/ajet.3996

Heinrich, E., Lee, C. B., \& Henderson, M. (2017). Editorial. Australasian Journal of Educational Technology, 33(1), i-iv. https://doi.org/10.14742/ajet.3732

Henderson, M., Bennett, S., \& Dalgarno, B. (2015). Editorial. Australasian Journal of Educational Technology, 31(1). https://doi.org/10.14742/ajet.2470

Henderson, M., Heinrich, E., \& Lee, C. (2016). Editorial. An argument for research significance. Australasian Journal of Educational Technology, 32(4), i-iii. https://doi.org/10.14742/ajet.3434 
Hirsch, J. (2005). An index to quantify an individual's scientific research output. Proceedings of the National Academy of Sciences of the United States of America, 102(46), 16569-16572. Retrieved from www.pnas.org/cgi/doi/10.1073/pnas.0507655102

Horta, H., \& Santos, J. (2016). The impact of publishing during PhD studies on career research publication, visibility, and collaborations. Research in Higher Education, 57(1), 28-50. https://doi.org/10.1007/s11162-015-9380-0

Hsu, Y.-C., Hung, J.-L., \& Ching, Y.-H. (2013). Trends of educational technology research: More than a decade of international research in six SSCI-indexed refereed journals. Educational Technology Research and Development, 61(4), 685-705. https://doi.org/10.1007/s11423-013-9290-9

Jackson, B. (2013). Completing a PhD by publication: A review of Australian policy and implications for practice. Higher Education Research and Development, 32(3), 355-368. https://doi.org/10.1080/07294360.2012.692666

Jones, M. (2013). Issues in doctoral studies - forty years of journal discussion: Where have we been and where are we going? International Journal of Doctoral Studies, 8(1), 83-104. Retrieved from http://ijds.org/Volume8/IJDSv8p083-104JonesFT129.pdf

Kamler, B. (2008). Rethinking doctoral publication practices: Writing from and beyond the thesis. Studies in Higher Education, 33(3), 283-294. https://doi.org/10.1080/03075070802049236

Kitto, K., Lupton, M., Davis, K., \& Waters, Z. (2017). Designing for student-facing learning analytics. Australasian Journal of Educational Technology, 33(5), 152-168. https://doi.org/10.14742/ajet.3607

Koh, J. (2017). Designing and integrating reusable learning objects for meaningful learning: Cases from a graduate programme. Australasian Journal of Educational Technology, 33(5), 136-151. https://doi.org/10.14742/ajet.3072

Krippendorff, K. (2013). Content analysis: An introduction to its methodology (3 ed.). Thousand Oaks, CA: Sage Publications.

Küçük, S., Aydemir, M., Yildirim, G., Arpacik, O., \& Göktaş, Y. (2013). Educational technology research trends in Turkey from 1990 to 2011. Computers \& Education, 68(1), 42-50. https://doi.org/10.1016/j.compedu.2013.04.016

Lamont, M. (2009). How professors think: Inside the curious world of academic judgement. Cambridge, MA: Harvard University Press.

Latchem, C. (2006). Editorial: A content analysis of the British Journal of Educational Technology. British Journal of Educational Technology, 37(4), 503-511. https://doi.org/10.1111/1467-8535.00119

Lavie, P. (2009). The race for the impact factor. Journal of Sleep Research, 18(3), 283-284. https://doi.org/10.1111/j.1365-2869.2009.00778.x

Lee, A., \& Kamler, B. (2008). Bringing pedagogy to doctoral publishing. Teaching in Higher Education, 13(5), 511-523. https://doi.org/10.1080/13562510802334723

Lee, Y., Driscoll, M., \& Nelson, D. (2004). The past, present, and future of research in distance education: Results of a content analysis. American Journal of Distance Education, 18(4), 225-251. https://doi.org/10.1207/s15389286ajde1804_4

Leon-Sarmiento, F., Leon-S., M., \& Contreras, V. (2007). El impacto de factor de impacto: ¿mito o realidad? Colombia Médica, 38(3), 290-296. Retrieved from http://www.redalyc.org/articulo.oa?id=28338313

Liu, Z., \& Wang, C. (2005). Mapping interdisciplinarity in demography: A journal network analysis. Journal of Information Science, 31(4), 308-316. https://doi.org/10.1177/0165551505054176

Marin, V., Duart, J., Galvis, A., \& Zawacki-Richter, O. (2018). Thematic analysis of the International Journal of Educational Technology in Higher Education (ETHE) between 2004 and 2017. International Journal of Educational Technology in Higher Education, 15(8), 1-7. https://doi.org/10.1186/s41239018-0089-y

Marin, V., Zawacki-Richter, O., Perez Garcias, A., \& Salinas, J. (2017). Educational technology trends in the Ibero-American world: 20 Years of Edutec-E Journal. EDUTEC. Revista Electrónica de Tecnología Educativa., 59(1), 1-24. https://doi.org/10.21556/edutec.2017.59.836

Mason, S. (2018). Publications in the doctoral thesis: Challenges for doctoral candidates, supervisors, examiners and administrators. Higher Education Research \& Development, 1-14. https://doi.org/10.1080/07294360.2018.1462307

McDonald, J., \& Loke, S.-W. (2016). Discursive constructions of teacher in an educational technology journal. Australasian Journal of Educational Technology, 32(5), 77-93. https://doi.org/10.14742/ajet.2787 
McGrail, M., Rickard, C., \& Jones, R. (2006). Publish or perish: A systematic review of interventions to increase academic publication rates. Higher Education Research \& Development, 25(1), 19-35. https://doi.org/10.1080/07294360500453053

Mouza, C., Yang, H., Pan, Y.-C., Ozden, S., \& Pollock, L. (2017). Resetting educational technology coursework for pre-service teachers: A computational thinking approach to the development of technological pedagogical content knowledge (TPACK). Australasian Journal of Educational Technology, 33(3), 61-76. https://doi.org/10.14742/ajet.3521

Mulligan, A., Hall, L., \& Raphael, E. (2013). Peer review in a changing world: An international study measuring the attitudes of researchers. Journal of the American Society for Information Science and Technology, 64(1), 132-161. https://doi.org/10.1002/asi.22798

Nagago, R. L., \& Bukovszki, E. (2016). Doctoral students’ perspectives on academic publishing. EduLingua, 2(1), 1-14. Retrieved from http://acta.bibl.u-szeged.hu/46439/1/edulingua_2016_001_001014.pdf

National Institute for Digital Learning (2017, December 20). The top 10 for 2017: Full list of articles and additional reflections [Blog post]. Retrieved from https://nidl.blog/2017/12/20/the-top-10-articles-for2017-the-full-list-and-additional-reflections/

Ouimet, M., Bedard, P.-O., \& Gelineau, F. (2011). Are the h-index and some of its alternatives discriminatory of epistemological beliefs and methodological preferences of faculty members? The case of social scientists in Quebec. Scientometrics, 88(1), 91-106. https://doi.org/10.1007/s11192-0110364-3

Panker, S. (2018). EdTech research - Where to publish, how to share (Part 1): Journal overview [Blog post]. Retrieved from http://blog.aace.org/review/edtech-research-publish-share-part-1-journal-overview/

Pare, A. (2010). Slow the presses: Concerns about premature publication. In C. Aitchison, B. Kamler, \& A. Lee (Eds.), Publishing pedagogies for the doctorate and beyond (pp. 30-46). London: Routledge.

Pechenkina, E. (2017). Developing a typology of mobile apps in higher education: A national case-study. Australasian Journal of Educational Technology, 33(4), 134-146. https://doi.org/10.14742/ajet.3228

Pegrum, M., Howitt, C., \& Striepe, M. (2013). Learning to take the tablet: How pre-service teachers use iPads to facilitate their learning. Australasian Journal of Educational Technology, 29(4), 464-479. https://doi.org/10.14742/ajet.187

Perez-Sanagustin, M., Nussbaum, M., Hilliger, I., Alario-Hoyos, C., Heller, R., Twining, P., \& Tsai, C. (2017). Research on ICT in K-12 schools - A review of experimental and survey-based studies in Computers \& Education 2011 to 2015. Computers \& Education, 104(1), A1-A15. https://doi.org/10.1016/j.compedu.2016.09.006

Perkins, R., \& Lowenthal, P. (2016). Open access journals in educational technology: Results of a survey of experienced users. Australasian Journal of Educational Technology, 32(3), 18-37. https://doi.org/10.14742/ajet.2578

Poitras, E., Doleck, T., Huang, L., Li, S., \& Lajoie, S. (2017). Advancing teacher technology education using open-ended learning environments as research and training platforms. Australasian Journal of Educational Technology, 33(3), 32-45. https://doi.org/10.14742/ajet.3498

Poth, C. (2018). The contributions of mixed insights to advancing technology-enhanced formative assessments within higher education learning environments: An illustrative example. International Journal of Educational Technology in Higher Education, 15(9), 1-19. https://doi.org/10.1186/s41239$\underline{018-0090-5}$

Print, M., \& Hattie, J. (1997). Measuring quality in universities: An approach to weighting research productivity. Higher Education, 33(4), 453-469. https://doi.org/10.1023/A:1002956407943

Redmond, P., Henderson, M., \& Heinrich, E. (2017). Editorial. Why can't I crack the code to getting published? Australasian Journal of Educational Technology, 33(5), i-iii. https://doi.org/10.14742/ajet.4088

Rodriguez, C. (2015). The dilemma of inclusivity in the globalization of academia. Cultural Studies of Science Education, 10(4), 1057-1062. https://doi.org/10.1007/s11422-015-9691-7

Sadowski, C., Pediaditis, M., \& Townsend, R. (2017). University students’ perceptions of social networking sites (SNSs) in their educational experiences at a regional Australian university. Australasian Journal of Educational Technology, 33(5), 77-90. https://doi.org/10.14742/ajet.2927

Saxena, A., Thawani, V., Chakarbarty, M., \& Gharpure, K. (2013). Scientific evaluation of the scholarly publications. Journal of Pharmacology \& Pharmacotherapeutics, 4(2), 125-129.

https://doi.org/10.4103/0976-500X.110894 
Shih, W.-L., \& Tsai, C.-Y. (2017). Students’ perception of a flipped classroom approach to facilitating online project-based learning in marketing research courses. Australasian Journal of Educational Technology, 33(5), 32-49. https://doi.org/10.14742/ajet.2884

Smith, A., \& Humphreys, M. (2006). Evaluation of unsupervised semantic mapping of natural language with Leximancer concept mapping. Behavior Research Methods, 38(2), 262-279. https://doi.org/10.3758/BF03192778

Smith, E. (2014). Voices from a small discipline: How the Australian vocational education and training discipline made sense of journal rankings. International Journal of Training Research, 12(3), 227-241. https://doi.org/10.1080/14480220.2014.11082044

Staller, K. (2017). Accountability metrics, politics, and qualitative inquiry: Demystifying bibliometrics. Qualitative Social Work, 16(4), 437-445. https://doi.org/10.1177/1473325017713881

Thalmann, S. (2014). Adaptation criteria for the personalised delivery of learning materials: A multi-stage empirical investigation. Australasian Journal of Educational Technology, 30(1), 45-60. https://doi.org/10.14742/ajet.235

Thomas, R., West, R., \& Rich, P. (2016). Benefits, challenges, and perceptions of the multiple article dissertation format in instructional technology. Australasian Journal of Educational Technology, 32(2), 82-98. https://doi.org/10.14742/ajet.2573

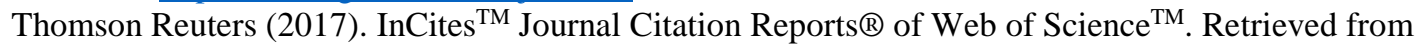
https://jcr.incites.thomsonreuters.com/JCRJournalHomeAction.action

Twining, P., Heller, R., Nussbaum, M., \& Tsai, C.-C. (2017). Some guidance on conducting and reporting qualitative studies. Computers \& Education, 106(1), A1-A9. https://doi.org/10.1016/j.compedu.2016.12.002

University of Wollongong Library (2014). Journal Impact Report. Retrieved from https://www.library.uow.edu.au/content/groups/public/@web/@lib/documents/doc/uow159436.pdf

Valtonen, T., Sointu, E., Kukkonen, J., Kontkanen, S., Lambert, M., \& Makitalo-Sigel, K. (2017). TPACK updated to measure pre-service teachers' twenty-first century skills. Australasian Journal of Educational Technology, 33(3), 15-31. https://doi.org/10.14742/ajet.2938

West, R., \& Borup, J. (2014). An analysis of a decade of research in 10 instructional design and technology journals. British Journal of Educational Technology, 45(4), 545-556. https://doi.org/10.1111/bjet.12081

West, R., \& Rich, P. (2012). Rigor, impact and prestige: A proposed framework for evaluating scholarly publications. Innovative Higher Education, 37(5), 359-371. https://doi.org/10.1007/s10755-012-9214-3

Zawacki-Richter, O., Alturki, U., \& Aldraiweesh, A. (2017). Review and content analysis of the International Review of Research in Open and Distance/Distributed Learning (2000-2015). International Review of Research in Open and Distributed Learning, 18(2), 1-21. Retrieved from http://www.irrodl.org/index.php/irrodl/article/view/2806/4090

Zawacki-Richter, O., Anderson, T., \& Tuncay, N. (2010). The growing impact of open access distance education journals: A bibliometric analysis. International Journal of E-Learning and Distance Education, 24(3). Retrieved from http://ijede.ca/index.php/jde/article/view/661/1210

Zawacki-Richter, O., \& Latchem, C. (2018). Exploring four decades of research in Computers \& Education. Computers \& Education, 122(1), 136-152. https://doi.org/10.1016/j.compedu.2018.04.001

Zawacki-Richter, O., \& Naidu, S. (2016). Mapping research trends from 35 years of publications in Distance Education. Distance Education, 37(3), 245-269. https://doi.org/10.1080/01587919.2016.1185079

Corresponding author: Melissa Bond, melissa.bond@uni-oldenburg.de

Australasian Journal of Educational Technology (C) 2018.

Please cite as: Bond, M. (2018). Helping doctoral students crack the publication code: An evaluation and content analysis of the Australasian Journal of Educational Technology. Australasian Journal of Educational Technology, 34(5), 167-181. https://doi.org/10.14742/ajet.4363 